\title{
Nerve growth factor levels and localisation in human asthmatic bronchi
}

\author{
C. Olgart Höglund*,\#, F. de Blay*, J-P. Oster", C. Duvernelle*, O. Kassel*, G. Pauli*,ף, \\ N. Frossard*
}

Nerve growth-factor levels and localisation in human asthmatic bronchi. C. Olgart Höglund, F. de Blay, J-P. Oster, C. Duvernelle, O. Kassel, G. Pauli, N. Frossard. (C) ERS Journals Ltd 2002.

ABSTRACT: Nerve growth factor (NGF) has recently been suggested to be an important mediator of inflammation. In support of this, serum levels of NGF have been shown to be enhanced in asthmatics. However, it has not yet been shown whether the levels of NGF are also altered locally in asthmatic airways, when compared with healthy subjects, and the localisation of potential sources of NGF in the human bronchus have not yet been described. The aim of the present study was to assess NGF levels in bronchoalveolar lavage fluid (BALF) from asthmatics and to compare them to those of control subjects. Furthermore, the authors wanted to localise potential sources of NGF in bronchial tissue, and to number NGF-immunopositive infiltrating cells in the bronchial submucosa.

BALF and bronchial biopsies were obtained from seven control subjects and seven asthmatic patients by fibreoptic bronchoscopy. NGF protein levels were quantified by enzyme-linked immunosorbent assay in BALF. NGF localisation was examined by immunohistochemistry on bronchial biopsy sections.

The asthmatics exhibited significantly enhanced NGF levels in BALF. Intense NGFimmunoreactivity was observed in bronchial epithelium, smooth muscle cells and infiltrating inflammatory cells in the submucosa, and to a lesser extent in the connective tissue. The asthmatics exhibited a higher number of NGF-immunoreactive infiltrating cells in the bronchial submucosa than control subjects.

This study provides evidence that nerve growth factor is locally produced in the airways, and shows that this production is enhanced in asthmatics. These findings suggest that nerve growth factor is produced by both structural cells and infiltrating inflammatory cells in human bronchus in vivo, and the authors suggest that the increase in nerve growth factor protein in bronchoalveolar lavage fluid observed in asthmatic patients may originate both from structural cells, producing increased nerve growth factor levels in inflammatory conditons, and from the increase in nerve growth factorimmunopositive cells determined in the bronchial submucosa. Eur Respir J 2002; 20: 1110-1116.
*Institut National de la Santé et de la Recherche Médicale (INSERM) U425, Neuroimmunopharmacologie Pulmonaire, Faculté de Pharmacie, Université Louis Pasteur Strasbourg I, Illkirch Cedex, and "Service de Pneumologie, Hôpitaux Universitaires de Strasbourg, Strasbourg, France. ${ }^{\#}$ Dept of Medicine, Division of Respiratory Medicine, Karolinska Hospital, Stockholm, Sweden.

Correspondence: C. Olgart Höglund, INSERM U425, Neuroimmunopharmacologie Pulmonaire, Faculté de Pharmacie, Université Louis Pasteur Strasbourg I, B.P. 24, 67401 Illkirch Cedex, France.

Fax: 33390244309

E-mail: caroline.olgart@fyfa.ki.se

Keywords: Airway, asthma, inflammation, nerve growth factor, neurotrophin

Received: January 162001

Accepted after revision: June 262002

This study was founded by INSERM C. Olgart Höglund was supported by the Swedish Research Council (Sweden), Torsten and Ragnar Söderberg's Foundation, Erik and Edith Fernström's Foundation, Comité Départemental du Bas-Rhin Contre les Maladies Respiratoires et la Tuberculose, UCB Institute of Allergy (Brussels, Belgium).
Nerve growth factor (NGF), the first neurotrophin discovered $>50$ yrs ago by LeVI-MonTALCINI [1], is an essential growth and survival factor for neurones. Recent studies suggest that NGF may also be an important inflammatory mediator. Thus, NGF activates $B$ - and T-lymphocytes, and may stimulate maturation, survival and activation of mast cells [2, 3]. Also, in animal airways, NGF evokes airway hyperresponsiveness [4-7]. Elevated levels of NGF are found in the serum in several inflammatory conditions, including asthma $[3,8]$. Furthermore, the levels of NGF are increased substantially in inflamed tissue $[9,10]$, and recent data also show an increase in NGF production in asthmatic airways following allergen provocation $[11,12]$. However, whether the levels of NGF are higher locally in the airways of the asthmatic population in comparison with healthy subjects has not yet been described.

A variety of cell sources have been shown to synthesise and secrete NGF in vitro. Among these are cells from the immune system, including mast cells [13-16], eosinophils [17, 18], lymphocytes [19, 20], monocytes [21] and macrophages [4, 22], as well as structural cells, such as fibroblasts, epithelial cells and smooth muscle cells [23-28]. Many of these cell types are important participants in the inflammatory condition of the asthmatic airways. However, information about the cell types capable of producing NGF in vivo in the human bronchus are at present scanty, and the cells capable of secreting NGF in asthmatic airways have not yet been described.

The aim of the present study was to compare the 
levels of NGF locally in the airways of asthmatic patients with those of control subjects. Furthermore, the authors wanted to localise the potential cell sources of NGF in bronchial tissue and to quantify the NGF-immunopositive inflammatory cells in the bronchial submucosa.

\section{Material and methods}

\section{Subjects}

This study included 14 subjects, of whom seven were patients with clinically stable, mild-to-moderate bronchial asthma (as defined in the International Consensus Report on Diagnosis and Management of Asthma, 1992 [29]), and seven were included as control subjects. The asthmatic patients were recruited from the authors' outpatient clinic. The clinical characteristics of the included subjects are displayed in tables 1 and 2. Each subject underwent a medical history, physical examination, and a pulmonary function testing by spirometry (forced expiratory volume in one second (FEV1)) (Autospiro, Minato AS 500; Mediprom, Paris, France).

Selection criteria for the asthmatic patients included a well-documented history of asthma and bronchial hyperresponsiveness, as assessed by a methacholine challenge test $(18-2,340 \mu \mathrm{g})$ at a screening visit, according to a standardised procedure, as described previously [30].

In the group of asthmatics (three males and four females, aged 21-26 yrs, median age $24 \mathrm{yrs}$ ), all but one were atopic, as indicated by weal and flare responses to one or more common allergen extracts used in the skin-prick testing. Fifteen common allergen extracts (Stallergènes, Fresnes, France) were tested according to a standard protocol. One patient informed that he had a food allergy to coriander, which provoked asthma symptoms, which was not included in the skin-prick test. The nonallergic asthmatic patient had a well-defined history of exercise-induced asthma. The asthmatic subjects had a mean \pm SEM baseline FEV1 prior to bronchoscopy of $84.4 \pm 5.5 \%$ (range 61.0-102.9) of the predicted normal values, and their geometric mean provocation dose causing a $20 \%$ fall in FEV1 (PD20) was $255.7 \mu \mathrm{g}$ (table 1).

Control subjects (three males and four females, aged $21-38$ yrs, median age 25 yrs) were all healthy nonatopic, nonallergic volunteers. The nonasthmatic subjects had a mean \pm SEM baseline FEV1 prior to bronchoscopy of $100.8 \pm 2.7 \%$ (range 90.3-113.1) of predicted normal values, and they exhibited no airway hyperresponsiveness, with a PD20 >2,340 $\mu$ g methacholine in all subjects (table 2).

All bronchodilators were withheld for at least $8 \mathrm{~h}$ before bronchoscopy. Most subjects were nonsmokers, except two subjects in each group (tables 1 and 2). The study was conducted out of the pollen season, and none of the allergic subjects had any animals or were exposed to the allergens against which they were sensitised for at least 1 month prior to the study. In addition, all subjects were free of respiratory infection for at least 1 month before the study, as well as from regular medication, other than the occasional use of inhaled bronchodilators in the group of asthmatics, or contraceptives. No systemic or inhaled steroids were used by any subject included in the study. The study was approved by the ethical committee of the authors' hospital, and all patients gave their written informed consent.

Table 1. - Clinical characteristics of patients with asthma

\begin{tabular}{lccccrr}
\hline Subject no. & Age & Sex & Smoking habits & Allergy/atopy & FEV1 \% pred & PD20 $\mu$ g \\
\hline 1 & 21 & F & C & Cat, dog, grass & 93 & 36 \\
2 & 25 & M & None & Mite & 83.8 & 72 \\
3 & 22 & M & None & Cat, mite & 61.0 & 18 \\
4 & 26 & F & None & Cat & 102.9 & 1620 \\
5 & 24 & F & Cat, grass, mite & 78.2 & 360 \\
6 & 24 & F & None & None & 97.1 & 1620 \\
7 & 22 & M & None & Birch, mite, mould, food & \\
& & & & &
\end{tabular}

FEV1: forced expiratory volume in one second; PD20: provocation dose causing a 20\% fall in FEV1; M: male; F: female; C: current smoker. ${ }^{\#}$ : 10 ; and ${ }^{\top}: 15$ cigarettes $\cdot$ day $^{-1}$; ${ }^{+}$: coriander.

Table 2. - Clinical characteristics of control subjects

\begin{tabular}{lccccrr}
\hline Subject no. & Age & Sex & Smoking habits & Allergy/atopy & FEV1 \% pred & PD20 $\mu$ g \\
\hline 1 & 38 & M & O & None & 90.3 & $>2340$ \\
2 & 25 & M & O & None & 101.8 & $>2340$ \\
3 & 21 & F & C & None & 95.1 & $>2340$ \\
4 & 28 & M & Cone & None & 99.4 & $>2340$ \\
5 & 26 & F & None & None & 103.6 & $>2340$ \\
6 & 23 & F & None & None & 13.1 & $>2340$ \\
7 & 24 & F & None & & 102.2 & $>2340$ \\
\hline
\end{tabular}

FEV1: forced expiratory volume in one second; PD20: provocation dose causing a 20\% fall in FEV1; M: male; F: female;

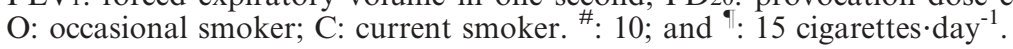




\section{Fibreoptic bronchoscopy}

Patients underwent fibroscopy between 4 days5 weeks after the methacholine challenge test. After premedication with diazepam (10 mg per os), local anaesthesia with $1 \%$ adrenaline-free xylocaine was directly applied to the upper respiratory tract, while a flexible fibreoptic bronchial fibroscope (BF P30; Olympus, Paris, France) was inserted through the nose into the trachea. Bronchial biopsies were taken from the subsegmental division of the main bronchi in the left lower and upper lobes using alligator forceps (Radial Jaw; Microvasive, La GarenneColombes, France). Bronchoalveolar lavage (BAL) was performed in the subsegment in the right middle lobe, by instilling $50 \mathrm{~mL}$ of sterile isotonic saline four times, at $37^{\circ} \mathrm{C}$, gently aspirated immediately after instillation, as recommended by the National Institutes of Health Workshop Summary and Guidelines, 1991 [31]. Patients received oxygen during bronchoscopy, an intravenous access was prepared, and adrenaline was readily available. Nebulisation with salbutamol was performed before and after the fibroscopy. Oximetry was recorded throughout the procedure and for $4 \mathrm{~h}$ after fibroscopy, with spirometry performed every hour for $4 \mathrm{~h}$.

\section{Preparation of bronchial biopsies and bronchoalveolar lavage fluid samples}

Bronchial biopsies were gently extracted from the forceps, and immediately placed in $10 \%$ buffered formaldehyde fixative at $4^{\circ} \mathrm{C}$ for $3 \mathrm{~h}$. Subsequently, the biopsies were embedded in paraffin and kept until use for immunohistochemistry.

The recovered BAL fluid (BALF) was kept on ice and immediately transported to the laboratory. The fluid was strained through a single layer of sterile cotton gauze to remove mucus. Cells were separated from the fluid phase by centrifugation at $400 \times g$ for $10 \mathrm{~min}$. An aliquot of cells resuspended in phosphatebuffered saline was taken to perform cell counting, to assess cell viability, and to characterise the different cell populations by cytocentrifugation, and May Giemsa Grünewald staining. Total cell counts and percentages of different cell types (differential cell counts) are presented in table 3 . The cell-free BALF was then centrifuged at $1500 \times g$ for $15 \mathrm{~min}$ at $4{ }^{\circ} \mathrm{C}$ to remove debris, then aliquoted and stored at $-80^{\circ} \mathrm{C}$ until it was analysed.

Table 3. - Cells in bronchoalveolar lavage

\begin{tabular}{lcc}
\hline & $\begin{array}{c}\text { Control } \\
\text { subjects }\end{array}$ & $\begin{array}{c}\text { Patients with } \\
\text { asthma }\end{array}$ \\
\hline Total cell concentration $10^{6} \cdot \mathrm{L}^{-1}$ & $80 \pm 31$ & $239 \pm 186$ \\
Macrophages \% & $95 \pm 1$ & $92 \pm 3$ \\
Lymphocytes \% & $4 \pm 0.8$ & $6 \pm 3$ \\
Neutrophils \% & $1 \pm 0.4$ & $0.8 \pm 0.4$ \\
Eosinophils \% & $0.2 \pm 0.1$ & $0.3 \pm 0.2$ \\
Epithelial cells \% & $0.5 \pm 0.3$ & $0.1 \pm 0.1$ \\
\hline
\end{tabular}

Data are presented as means \pm SEM.
Determination of nerve growth factor by enzymelinked immunosorbent assay

The levels of NGF protein were quantified in 1:2 diluted BALF from asthmatic patients and control subjects with a commercially available, highly sensitive NGF-specific two-site enzyme-linked immunosorbent assay (ELISA)-kit according to the procedure indicated by the manufacturer (Promega, Madison, WI, USA), and as reported by other authors [11]. Briefly, 96-well immunoplates (MaxiSorp ${ }^{\mathrm{TM}}$; Nunc, Roskilde, Denmark) were coated with a polyclonal goat anti-human NGF antibody in a coating buffer ( $25 \mathrm{mM}$ carbonate buffer, $\mathrm{pH}$ 9.7). After an overnight incubation at $4{ }^{\circ} \mathrm{C}$, plates were washed $(20 \mathrm{mM}$ Tris$\mathrm{HCl}, 150 \mathrm{mM} \mathrm{NaCl}$ with $0.05 \%$ (v/v) Tween $\mathrm{R}-20$ ), and incubated in a blocking buffer (supplied by the manufacturer) for $1 \mathrm{~h}$. The diluted BAL samples and the standard recombinant human NGF were incubated in the wells at room temperature for at least $6 \mathrm{~h}$, and washed. Both samples and the recombinant NGF were diluted in the blocking buffer, as suggested by the manufacturer. Rat monoclonal anti-NGF antibody $\left(0.25 \mu \mathrm{g} \cdot \mathrm{mL}^{-1}\right)$ was added for an overnight incubation at $4{ }^{\circ} \mathrm{C}$. After washing, anti-rat horseradish peroxidase-conjugated immunoglobulin ( $\mathrm{Ig}) \mathrm{G}$ was added for a $2.5 \mathrm{~h}$ incubation period. Finally, the substrate $\left(0.02 \% 3,3^{\prime}, 5,5^{\prime}\right.$-tetramethylbenzidine and $0.01 \%$ hydrogen peroxidase) was added. The colourimetric reaction was stopped after $10 \mathrm{~min}$ with $1 \mathrm{M}$ phosphoric acid, and the optical density was measured at $450 \mathrm{~nm}$. All measurements were performed in duplicate. In control experiments, the primary antibody was withheld, leading to the expected undetectable signal. The technique allowed detection of NGF in the range of $3.9-500 \mathrm{pg} \cdot \mathrm{mL}^{-1}$.

\section{Nerve growth factor immunolocalisation on bronchial biopsy sections}

Serial $4 \mu \mathrm{m}$ sections were deparaffinised in xylene, stepwise rehydrated through graded ethanol, and washed in Tris-buffered saline (TBS; $20 \mathrm{mM}$ Trizma base, $150 \mathrm{mM} \mathrm{NaCl}$, pH 7.6). Following antigen retrieval treatment with $0.1 \%$ pronase $\mathrm{E}$ in TBS for $8 \mathrm{~min}$ at room temperature (Sigma Chemical Co., St. Louis, MO, USA), unspecific protein binding was blocked with a blocking buffer containing foetal bovine serum (FBS) (10\% v/v) (GIBCO BRL, Cergy Pontoise, France), and bovine serum albumin (BSA) $(1 \% \mathrm{w} / \mathrm{v})$ (Sigma) in TBS for $30 \mathrm{~min}$ at room temperature. Sections were then incubated overnight at $4^{\circ} \mathrm{C}$ with a rabbit anti-human NGF polyclonal antibody (1:100) (Santa Cruz Biotechnology, Santa Cruz, CA, USA), followed by incubation for $2 \mathrm{~h}$ at room temperature with a donkey biotinylated anti-rabbit $\mathrm{IgG}$ antiserum (1:200) (Amersham Life Science, Orsay, France), an Extravidin-alkaline phosphatase conjugate (Sigma), and finally with Fast Red TR/ Naphtol AS-MX (Sigma) for development of the immune reaction. The anti-human NGF antibody recognises an epitope mapping the amino-terminus of the mature form of NGF of human origin, 
noncrossreactive with brain-derived neurotrophic factor, neurotrophin-3 or -4 . Negative controls were performed by replacing the primary antibody by its control isotype immunoglobulin from the same species, and was performed in parallel for the different samples. All antibodies were diluted in blocking buffer. Sections were washed extensively in TBS between incubations with antibodies, conjugate and substrate. Finally, sections were washed in distilled water and counterstained with Mayer's haematoxylin, briefly dried and mounted in a gelatine-glycerol solution. A qualitative evaluation of the sections were performed by light microscopy using a Zeiss Axiophot (Oberkochen, Germany) at a magnification of $\times 200$, $\times 400$ and/or $\times 640$.

Quantification of nerve growth factor-immunopositive inflammatory cells infiltrating the bronchial tissue

Slides were coded and examined under a light microscope (magnification $\times 400)$ (Zeiss Axiophot) by three investigators. NGF-immunopositive infiltrating inflammatory cells were counted in the submucosa, excluding the epithelium. The images were then digitalised with a high-performance charge-coupled device (CCD) camera (Cohu Inc., San Diego, CA, USA), and areas were measured by an image analyser (SIS analysis; Olympus). NGF-immunopositive inflammatory cells were counted in 2-3 different sections from each specimen, and counts were averaged. Results are expressed as number of NGF-immunopositive inflammatory cells per $\mathrm{mm}^{2}$.

\section{Statistical analysis}

Group data were expressed as mean values \pm SEM and range. Differences between groups were evaluated with the nonparametric Mann-Whitney sum-rank test. Values of $\mathrm{p}<0.05$ were considered significant.

\section{Results}

All 14 subjects, seven asthmatics and seven controls, completed the study according to the defined study protocol.

Nerve growth factor protein levels in bronchoalveolar lavage fluid

Detectable levels of NGF were determined in BALF from control subjects $\left(53.9 \pm 20.2 \mathrm{pg} \cdot \mathrm{mL}^{-1}\right)$. Significantly higher $(121.5 \%, \mathrm{p}<0.05)$ levels of NGF protein were observed in BALF from the asthmatic patients $\left(119.4 \pm 30.6 \mathrm{pg} \cdot \mathrm{mL}^{-1}\right)$ as compared with control subjects (fig. 1).

Nerve growth factor immunolocalisation in bronchial sections

NGF was immunolocalised on bronchial biopsy sections from control subjects and asthmatic patients.

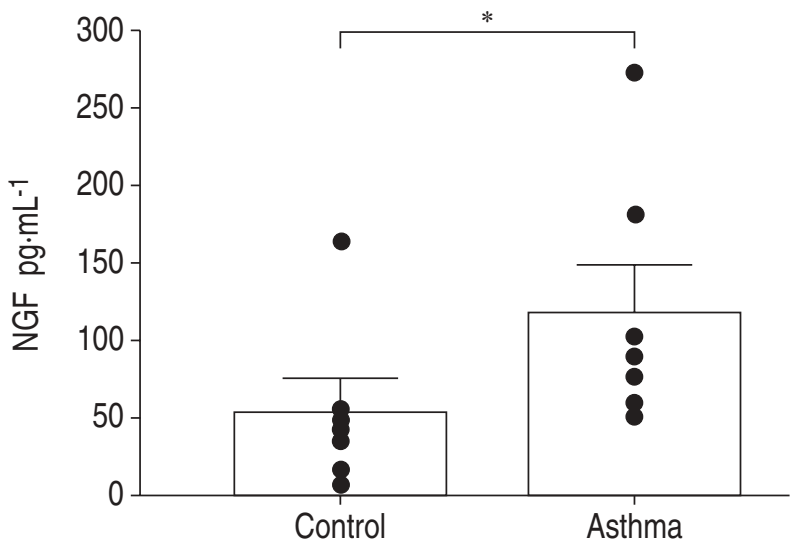

Fig. 1.- Nerve growth factor (NGF) protein levels in bronchoalveolar fluid from control subjects and asthmatic patients. NGF levels were quantified by enzyme-linked immunosorbent assay. Individual values are represented as dots and bars indicate means \pm SEM. $*: \mathrm{p}<0.05$ between groups.

An intense NGF-immunolabelling was observed within the bronchial epithelium (fig. 2 a-d), even though epithelium from the asthmatic bronchi showed mild shedding (fig. 2c and d). The bronchial smooth muscle layer was also intensely labelled (fig. $2 \mathrm{~b}$ and d), whereas less intense immunoreactivity was observed in the connective tissue (fibroblasts) (fig. 2). Furthermore, an intense positive signal for $\mathrm{NGF}$ was observed within infiltrating inflammatory cells in the submucosa (fig. 2c-e). The majority of these cells had a mononuclear appearance. The negative control (fig. 2f), performed by replacing the primary antibody by its control isotype from the same species, was entirely negative.

Quantification of infiltrating nerve growth factorimmunopositive cells in the bronchial submucosa

In bronchial biopsies from asthmatics, a significant increase in the number of NGF-immunopositive cells infiltrating the submucosa was determined in comparison with the submucosa of control subjects $(30.4 \pm 7.3$ and $12.2 \pm 3.4$, respectively, $148.6 \%, \mathrm{p}<0.05)$.

\section{Discussion}

The present study provides evidence of NGF production in the human airways. More importantly, the hypothesis that elevated levels of NGF may be present locally in the airways of asthmatics as compared with healthy subjects has been validated. NGF has also been immunolocalised in bronchial biopsy sections, showing intense labelling of the bronchial epithelium, smooth muscle cells and infiltrating mononuclear cells in the submucosa, with a lower intensity of labelling in fibroblasts, both in asthmatic and control subjects. Finally, an increase in NGF-immunopositive cells in the submucosa has been determined in asthmatics as compared with control subjects.

The data present here show that the NGF protein 

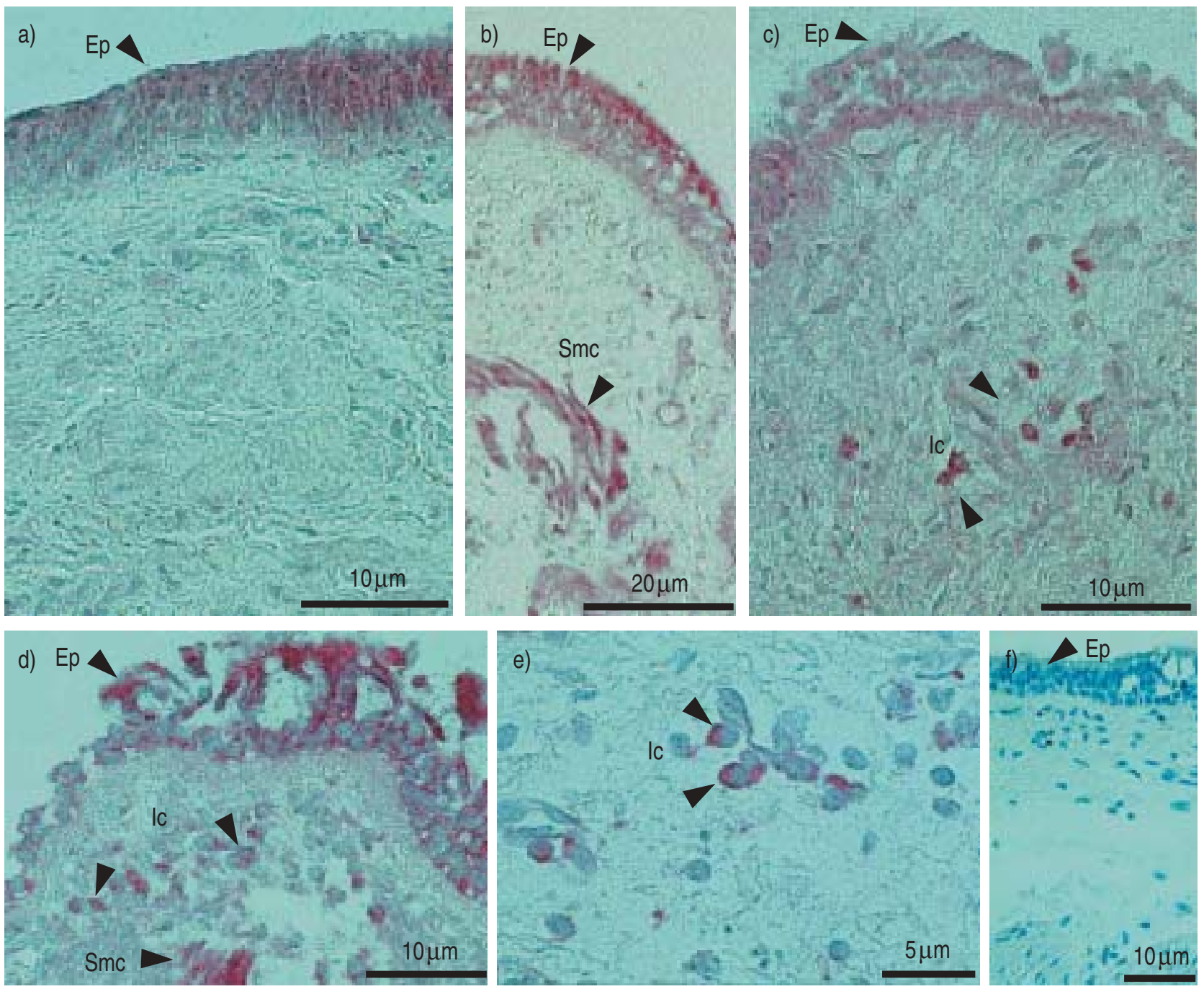

Fig. 2. - Nerve growth factor (NGF) immunolocalisation on bronchial biopsy sections from control subjects (a, b) and asthmatic patients (c-f). Intense labelling was observed in bronchial epithelium (Ep), smooth muscle cells (Smc) and infiltrating inflammatory cells (Ic) in the submucosa, showing cytoplasmic localisation, both in control subjects and asthmatic patients. A negative control is shown (f), where the anti-human NGF antibody was replaced by its control isotype immunoglobulin.

can be detected in BALF from healthy subjects, and that enhanced levels are found in BALF from asthmatics. This is in agreement with, and extends the results obtained by BonINI et al. [8], where enhanced levels of NGF could be detected in serum from patients suffering from severe asthma. Furthermore, the present finding of locally enhanced NGF levels found at the site of inflammation in the airways of asthmatics, is consistent with the enhanced levels of NGF detected in the nasal lavage fluid from patients with rhinitis as compared with control subjects [32]. The increase in NGF messenger ribonucleic acid (mRNA) expression reported in bronchial tissue after repeated inhalation of allergen at low nonprovocative doses [12], and the enhanced NGF protein levels reported in BALF after a positive allergen challenge in asthmatics [11], further support altered NGF production in human airways in asthma. It has been shown here that the asthmatic population may have a local increased level of NGF in the airways.
The detection of basal NGF levels in BALF from healthy subjects corresponds with the immunostaining of bronchial biopsies from control subjects, where NGF was immunolocalised to the bronchial epithelium, the smooth muscle cells, the fibroblasts and in few infiltrated cells in the bronchi of healthy subjects. These findings are in agreement with the presence of NGF mRNA transcripts in scrapping specimens from upper airway epithelium and mucosa obtained from healthy control subjects [32]. This suggests that NGF is a factor which is also expressed in human airways under healthy conditions. A number of studies in several cell systems in vitro further support the constitutive production of NGF. For instance, human lung fibroblasts [27], airway epithelial cells [25, 26], airway smooth muscle cells [28], and cells from the immune system, such as lymphocytes [19, 20], mast cells [13-16] and eosinophils $[17,18]$ may produce and secrete NGF in vitro. However, less is known about the situation in vivo and in particular in the human airways. The present study provides evidence for and 
supports the view that multiple sources of NGF are present in the human bronchus and that both structural cells and infiltrating cells may be producers of NGF.

In biopsy sections from asthmatic airways, as in bronchi from healthy subjects, an intense staining for $\mathrm{NGF}$ was found in the bronchial epithelium, the smooth muscle, in infiltrating inflammatory cells and to a lesser extent in connective tissue (fibroblasts). In the bronchial biopsies of the asthmatic subjects, a larger number of infiltrating NGF-immunopositive cells was determined than in control subjects. Hence, the infiltrating inflammatory cells may be one source of the enhanced levels of NGF in asthmatic airways. The majority of these cells had a mononuclear appearance. As determined in vitro, immune/inflammatory cells that are capable of producing NGF include lymphocytes [19-20], eosinophils [17, 18], and mast cells [13-16]. In the literature, elevated levels of NGF have been described in response to the activation of several cell types, including structural and immune/ inflammatory cells. In particular, T-helper 2 (Th2) lymphocytes and mast cells express and secrete enhanced levels of NGF in vitro in response to activation [16, 19-20]. Furthermore, structural cells of the lung, such as fibroblasts, epithelial cells and smooth muscle cells, also secrete enhanced amounts of NGF in response to the pro-inflammatory and asthma-associated cytokines interleukin-1 $\beta$ and tumour necrosis factor- $\alpha$ in vitro [25-28, 33]. Thus, multiple sources of the excessively secreted NGF in asthma are probable, either related to structural cells expressing more NGF in asthmatic inflammatory conditions or to a greater number of infiltrated inflammatory cells in the asthmatic airways expressing NGF in the same or in greater quantities. The current authors suggest that chronic activation of both infiltrating and resident cells of the airways in asthmatics may lead to an increased NGF secretion as detected in serum [8] and bronchoalveolar lavage (as in this study).

At present, the precise role of NGF in the human lung and airways has not yet been described, although $\mathrm{NGF}$ is now referred to as an inflammatory mediator $[2,3,6,7,33]$. It has been suggested that NGF may function as a paracrine survival factor for immune/ inflammatory cells, as well as for peripheral neurones $[2,3]$. With regards the inflammatory/immune cells, NGF is known to activate B- and T-cells, and to stimulate maturation, survival and activation of mast cells and eosinophils expressing the high-affinity cell surface receptor for NGF (TrkA) [2, 3, 33, 34]. In neurones, NGF may alter transmitter content and excitability [2, 3, 33]. Hence, inflammatory/immune cells as well as neurones may be a target for the elevated levels of NGF secreted in the airways in asthma. Several new roles for NGF in the airways have been addressed by studies performed in guinea pigs and mice. More recently, NGF has been shown to evoke airway hyperresponsiveness [4-7], an effect thought to be mediated through neuronal "sensitisation", either via a direct effect of NGF on the sensory nerves or as an indirect component involving some inflammatory cells, such as the mast cell $[14,15,33]$ or the Th2 cell [4, 20,33]. Hence, there is increasing evidence for the involvement of NGF in a variety of pathological conditions of the lung and airways, in particular in bronchial hyperresponsiveness. However, less is known about the human airways in healthy or asthmatic subjects. Other issues, such as how NGF may participate in the local inflammation of the human airways and whether NGF can be linked to asthma-associated symptoms such as bronchial hyperresponsiveness in humans in vivo, as was also suggested by studies in asthmatics inhaling allergen $[11,12]$, need to be investigated further.

In conclusion, the present authors report that nerve growth factor is locally produced in the airways and that its production is enhanced in the bronchoalveolar lavage fluid from asthmatic patients as compared to controls. In addition, the finding of an intense nerve growth factor immunolabelling on bronchial biopsy sections further supports the concept that nerve growth factor is produced by both structural cells and infiltrating inflammatory cells in the human bronchus in vivo. The authors suggest that the increase in nerve growth factor protein in bronchoalveolar lavage fluid observed in asthmatic patients may originate from the increase in nerve growth factorimmunopositive cells observed in the bronchial submucosa of asthmatics.

Acknowledgements. The authors would like to thank B. Gasser (Institut d'Anatomie Pathologique) and G. Massard (Service de Chirurgie Thoracique, Hôpitaux Universitaires de Strasbourg, France) for fruitful discussions, and E. Mathieu for excellent technical assistance.

\section{References}

1. Levi-Montalcini R. The nerve growth factor 35 years later. Science 1987; 237: 1154-1162.

2. Levi-Montalcini R, Skaper SD, Dal Toso R, Petrelli L, Leon A. Nerve growth factor: from neurotrophin to neurokine. Trends Neurosci 1996; 19: 514-520.

3. Aloe L, Bracci-Laudiero L, Bonini S, Manni L. The expanding role of nerve growth factor: from neurotrophic activity to immunologic disease. Allergy 1997; 52: 883-994.

4. Braun A, Appel E, Baruch R, et al. Role of nerve growth factor in a mouse model of allergic airway inflammation and asthma. Eur J Immunol 1998; 28: 3240-3251

5. Hoyle GW, Graham RM, Finkelstein JB, Nguyen KP, Gozal D, Friedman M. Hyperinnervation of the airways in transgenic mice overexpressing nerve growth factor. Am J Respir Cell Mol Biol 1998; 18: 149-157.

6. de Vries A, Dessing MC, Engels F, Henricks PAJ, Nijkamp FP. Nerve growth factor induces a neurokinin-1 receptor-mediated airway hyperresponsiveness in guinea pigs. Am J Respir Crit Care Med 1999; 159: 1541-1544.

7. Friberg SG, Olgart Höglund C, Gustafsson LE. Nerve growth factor increases airway responsiveness and decreases levels of exhaled nitric oxide during 
histamine challenge in an in vivo guinea pig model. Acta Physiol Scand 2001; 173: 239-245.

8. Bonini S, Lambiase A, Bonini S, et al. Circulating nerve growth factor levels are increased in humans with allergic diseases and asthma. Proc Natl Acad Sci USA 1996; 93: 10955-10960.

9. Donnerer J, Schuligoi R, Stein C. Increased content and transport of substance $\mathrm{P}$ and calcitonin generelated peptide in sensory nerves innervating inflamed tissue: evidence for a regulatory function of nerve growth factor in vivo. Neuroscience 1992; 49: 693-698.

10. Woolf CJ, Safieh-Garabedian B, Ma Q-P, Crilly P, Winter J. Nerve growth factor contributes to the generation of inflammatory sensory hypersensitivity. Neuroscience 1994; 62: 327-331.

11. Virchow JC, Julius P, Lommatzsch M, Luttmann W, Renz H, Braun A. Neurotrophins are increased in bronchoalveolar lavage fluid after segmental allergen provocation. Am J Respir Crit Care Med 1998; 158: 2002-2005.

12. Kassel O, De Blay F, Duvernelle C, et al. Local increase in the number of mast cells and expression of nerve growth factor in the bronchus of asthmatic patients after repeated inhalation of allergen at lowdose. Clin Exp Allergy 2001; 31: 1432-1440.

13. Leon A, Buriani A, Dal Toso R, et al. Mast cells synthesize, store, and release nerve growth factor. Proc Natl Acad Sci USA 1994; 91: 3739-3743.

14. Nilsson G, Forsberg-Nilsson K, Xiang Z, Hallbààk F, Nilsson K, Metcalfe DD. Human mast cells express functional TrkA and are a source of nerve growth factor. Eur J Immunol 1997; 27: 2295-2301.

15. Tam SY, Tsai M, Yamaguchi M, Yano K, Butterfield JH, Galli SJ. Expression of functional TrkA receptor tyrosine kinase in the HMC-1 human mast cells. Blood 1997; 90: 1807-1820.

16. Xiang X, Nilsson G. IgE receptor-mediated release of nerve growth factor by mast cells. Clin Exp Allergy 2000; 30: 1379-1386.

17. Solomon A, Aloe L, Pe'er J, et al. Nerve growth factor is preformed in and activates human peripheral blood eosinophils. J Allergy Clin Immunol 1998; 102: 454 460.

18. Kobayashi H, Gleich GJ, Butterfield JH, Kita H. Human eosinophils produce neurotrophins and secrete nerve growth factor on immunological stimuli. Blood 2002; 99: 2214-2220.

19. Santambrogio L, Benedetti M, Chao MV, et al. Nerve growth factor production by lymphocytes. J Immunol 1994; 153: 4488-4495.

20. Lambiase A, Bracci-Laudiero L, Bonini S, et al. Human CD4+ $\mathrm{T}$ cell clones produce and release nerve growth factor and express high affinity nerve growth factor receptors. J Allergy Clin Immunol 1997; 100: 408-414.

21. Ehrhard PB, Ganter U, Stalder A, Bauer J, Otten U. Expression of functional trk protooncogen in human monocytes. Proc Natl Acad Sci USA 1993; 90: 54235427.

22. Mallat M, Houlgatte R, Brachet P, Prochiantz A. Lipopolysaccharide-stimulated rat brain macrophages release NGF in vitro. Dev Biol 1989; 133: 309-311.

23. Murase K, Murakami Y, Takayanagi K, Furukawa Y, Hayashi K. Human fibroblast cells synthezise and secrete nerve growth factor in culture. Biochem Biophys Res Commun 1992; 184: 373-379.

24. Ueyama T, Hamada M, Hano T, Nishio I, Masuyama Y, Furukawa S. Production of nerve growth factor by cultured vascular smooth muscle cells from spontanously hypertensive and Wistar-Kyoto rats. J Hypertens 1993; 11: 1061-1065.

25. Fox AJ, Patel HJ, Barnes PJ, Belvisi MG. Release of nerve growth factor by pulmonary epithelial cells: role in airway inflammatory disease. Eur $J$ Pharmacol 2001; 424: 159-162.

26. Pons F, Freund V, Kuissu H, Mathieu E, Olgart C, Frossard N. Nerve growth factor secretion by human lung epithelial A549 cells in pro- and antiinflammatory conditions. Eur Resp J 2001; 428: 365-369.

27. Olgart C, Frossard N. Human lung fibroblasts secrete nerve growth factor: effect of inflammatory cytokines and glucocorticoids. Eur Resp J 2001; 18: 115-121.

28. Freund V, Pons F, Joly V, Mathieu E, Martinet N, Frossard N. Upregulation of NGF expression by human airway smooth muscle cells in inflammatory conditions. Eur Resp J 2002, in press.

29. International Consensus Report on Diagnosis and Management of Asthma. Allergy 1992; 47: Suppl.13.

30. de Blay F, Krieger P, Spirlet F, et al. Repeated inhalation of low doses of cat allergen that do not induce clinical symptoms increases bronchial hyperresponsivness and eosinophil cationic protein levels. Int Arch Allergy Immunol 1999; 120: 158-165.

31. National Institute of Health Workshop Summary and Guidelines: Investigative use of bronchoscopy, lavage and bronchial biopsies in asthma and other airway diseases. J Allergy Clin Immunol 1991; 88: 808-814.

32. Sanico AM, Stanisz AM, Gleeson TD, et al. Nerve growth factor expression and release in allergic inflammatory disease of the upper airways. Am J Respir Crit Care Med 2000; 161: 1631-1635.

33. Olgart C, Frossard N. Nerve growth factor and asthma. Eur Respir Rev 2000; 10: 326-328.

34. Simone MD, De Santis S, Vigneti E, Papa G, Amadori S, Aloe L. Nerve growth factor: a survey of activity on immune and hematopoietic cells. Hematol Oncol 1999; 17: 1-10. 